\title{
The efficiency of emergency cerclage for the prevention of pregnancy losses and preterm labor
}

\author{
Necip Cihangir Yılanlıoğlu (D), Altuğ Semiz (D), Resul Arısoy \\ Gynecology and Obstetrics Clinic, Memorial Şişli Hospital, Istanbul, Turkey
}

\begin{abstract}
Objective: To analyze the gestational outcomes of the cases who underwent emergency cerclage in our clinic.

Methods: The cases which underwent emergency cerclage in Memorial Şişli Hospital between 2005 and 2017 were analyzed retrospectively. Of the cases with singleton pregnancy, those without pain and uterine contraction, those with visible cervical dilatation and amniotic membrane or those with prolapsed to vagina were included in the study. The cases without cervical dilation, multiple pregnancies, the cases which clinically have chorioamnionitis, preterm premature rupture of membrane, vaginal bleeding and ablatio placentae and the pregnant women with a chronic disease were excluded from the study. The clinical characteristics and gestational outcomes of the cases were analyzed.

Results: We included a total of 28 cases in our study. Mean week of gestation was $20.9 \pm 3.2$ during the cerclage procedure, delivery week was $32.4 \pm 5.5$, and mean period between cerclage and delivery was $81.1 \pm 42.5$ days $(11.6 \pm 6.08$ weeks). Late pregnancy loss was seen in two (7.1\%) cases. The rates of preterm labor (<37 weeks) and extremely early preterm labor ( $<28$ weeks) were $76.9 \%$ and $14.3 \%$, respectively. Mean birth weight was found $2268 \pm 984 \mathrm{~g}$. It was reported that three cases died at the intensive care unit, and the neonatal mortality rate was $11.5 \%$. The rate of bringing infants to home was $82.1 \%$ (23 infants).

Conclusion: In our study, we showed that the rates of pregnancy loss and preterm labor can be decreased by cerclage procedure in the cases with cervical insufficiency requiring emergency cerclage.
\end{abstract}

Keywords: Emergency cerclage, pregnancy loss, preterm labor, cervical insufficiency

\section{Introduction}

Cervical insufficiency is one of the most important reasons of second trimester pregnancy losses and preterm labor, and it is defined as the condition where cervix is

\section{Özet: Gebelik kayıpları ve preterm doğumun önlen-} mesinde acil serklajın etkinliği

Amaç: Kliniğimizde yapılan acil serklaj olgularının gebelik sonuçlarını değerlendirmek.

Yöntem: 2005-2017 yılları arasında Memorial Şişli Hastanesinde acil serklaj yapılan olgular retrospektif olarak değerlendirildi. Olgulardan, ağrısı ve uterin kontraksiyonu olmayan, servikal açıklı̆̆ı ve amniyotik membranı görünen veya vajene prolabe olan tekil gebelikler çalışmaya dahil edildi. Servikal açıklığı olmayan olgular, çoğul gebelikler, klinik olarak koryoamnionit, preterm erken membran rüptürü, vajinal kanama ve plasenta dekolmanı olan olgular ve yine kronik hastalı̆̆ olan gebeler çalışma dışı bırakıldı. Olguların klinik özellikleri ve gebelik sonuçları analiz edildi.

Bulgular: Çalışmamıza 28 olgu dahil edildi. Serklaj işleminin yapıldığı ortalama gebelik haftası $20.9 \pm 3.2$, doğum haftası $32.4 \pm 5.5$ ve serklaj ile doğum arasındaki ortalama süre $81.1 \pm 42.5$ gün $(11.6 \pm 6.08$ hafta) olarak bulundu. İki olguda (\%7.1) geç gebelik kaybı saptandı. Preterm (<37 hafta) doğum oranı \% 76.9 ve aşırı erken (<28 hafta) preterm doğum oranı da \% 14.3 olarak saptandi. Ortalama doğum kilosu $2268 \pm 984 \mathrm{~g}$ bulundu. Üç olgunun yoğun bakımda ex olduğu ve neonatal ölüm oranının da \% $11.5 \mathrm{ol}-$ duğu bildirildi. Bebeğini evine götürme oranı \%82.1 (23 bebek) bulundu.

Sonuç: Çalışmamızda acil serklaj gereksinimi ve servikal yetmezliği olan olgularda yapılan serklaj işlemi ile gebelik kaybı ve erken doğum oranlarının azaltılabileceği gösterilmiştir.

Anahtar sözcükler: Acil serklaj, gebelik kaybı, preterm doğum, servikal yetmezlik.

unable to maintain pregnancy without uterine contraction. Typically, it is characterized by acute and painless cervical dilation and pregnancy loss at the second trimester. ${ }^{[1]}$ The incidence of cervical insufficiency is

Correspondence: Resul Arısoy, MD. Gynecology and Obstetrics Clinic, Memorial Şişli Hospital, Istanbul, Turkey.

e-mail: drresular@hotmail.com / Received: December 8, 2018; Accepted: January 21, 2019

Please cite this article as: Yllanlığlu NC, Semiz A, Arısoy R. The efficiency of emergency cerclage for the prevention of pregnancy losses and preterm labor. Perinatal Journal 2019;27(1):1-5. doi:10.2399/prn.19.0271001 
$0.1-2 \%$ while it is $15 \%$ in pregnancies with the history of recurrent pregnancy loss between 16 and 28 weeks of gestation. ${ }^{[2]}$ The reason of cervical insufficiency is not known mostly, but it is considered to be a structural defect in cervicoisthmic junction. It has also been reported that decidual inflammation, intrauterine infection, hemorrhage, excessive uterine distension, acquired and structural functional defects (cervical conization, cervical laceration etc.), Mullerian anomalies, and Ehlers-Danlos syndrome may be associated with cervical insufficiency. ${ }^{[3-6]}$

Today, surgical and non-surgical methods are recommended for the treatment of cervical insufficiency. Surgical approaches include transvaginal and transabdominal cervical cerclage. Standard transvaginal cerclage method used widely was first defined by Shirodkar in $1955,{ }^{[7]}$ and it was modified by McDonald in $1957 .{ }^{[8]}$ McDonald procedure was defined as the purse string suture from non-resorbed material to cervicovaginal junction. Cerclage indications in the singleton pregnancies are painless pregnancy loss or cerclage history at the second trimester (cerclage - prophylactic cerclage with history indication), spontaneous preterm labor history (<34 weeks), cervical length being less than $25 \mathrm{~mm}$ before 24 weeks of gestation (cerclage with ultrasound indication) and painless cervical dilation at the second trimester (emergency or rescue cerclage).

In our study, we aimed to discuss the outcomes of the cases which underwent emergency cerclage.

\section{Methods}

The cases with 13-26 weeks of singleton pregnancy that were operated due to emergency cervical insufficiency at Memorial Şişli Hospital between 2005 and 2017 were analyzed retrospectively. Of the cases, those in need of emergency cerclage, those without pain and uterine contraction, those with $1-5 \mathrm{~cm}$ of cervical dilatation and visible amniotic membrane or those with prolapsed to vagina were included in the study. Cases with close cervix were excluded from the study. Also, multiple pregnancies and the cases which clinically have chorioamnionitis, preterm premature rupture of membrane, vaginal bleeding, ablatio placentae and chronic disease were excluded from the study

The patients were administered 1 dose of indomethacin (Endol) $100 \mathrm{mg}$ suppository right after hospitalization and emergency cerclage was planned. The surgical procedure was performed under general anesthe- sia at dorsal lithotomy position. The cleaning of vulva and vagina was performed through two steps (after the skin first, the vagina which is not very deep and covering, deep vagina and fornices by using valve speculum). Retraction was performed by new valves by removing the tools used for cleaning. As suture material, $5 \mathrm{~mm}$ Mersilene tape (MERSILENE ${ }^{\circledR}$ Polyester Fiber Suture, ETHICON; Johnson \&Johnson, New Brunswick, NJ, ABD) was used in all cases. McDonald technique was used as cerclage method. Cervical length and the position of suture material were evaluated by transvaginal ultrasonography (Voluson 730, General Electric Healthcare, Chicago, IL, USA). As intraoperative prophylactic, single dose cefazolin was administered intravenously. Later, cefuroxime (Zinnat, Zinacef) $500 \mathrm{mg} 2 \times 1$ was administered orally for 5 days. Endol $100 \mathrm{mg}$ suppository given at the hospitalization was administered for 3 days with the dose of $2 \times 1$. Progesterone or any other tocolytics was not administered for the follow-up. After 24 weeks, corticosteroid prophylaxis [Celestone Chronodose $1 \mathrm{ml}$ (betamethasone acetate + betamethasone sodium phosphate) $1 \times 2$ intramuscular, and a second dose 24 hours after the first dose) was administered. The patients were called for follow-up 1 and 3 weeks after their discharge. They were followed up with an interval of 2 weeks. In cases that reached the term, cerclage materials were removed at 37 weeks of gestation.

The demographic and clinical characteristics of the cases were provided from the patient files and hospital data system. Age, body mass index, obstetric history, gravida and parity, weeks of gestation, admission reasons, cervical dilation and effacement, cervical length measurements, presence of additional clinical characteristics, cervical length after cerclage and gestational outcomes of the patients were recorded. Missing items in the data were completed by contacting patients via phone.

SPSS 20 (SPSS Inc., Chicago, IL, USA) was used for statistical analysis. Descriptive statistical analyses (mean, standard deviation, standard error) were performed. Parameters were evaluated by Kolmogorov-Smirnov test to understand if they have normal distribution. While independent samples $t$ test was used for the comparison of the parameters displaying normal distribution, MannWhitney $\mathrm{U}$ test was used for the comparison of the parameters not displaying normal distribution. $\mathrm{p}<0.05$ was considered statistically significant. 
Table 1. Clinical characteristics of the cases.

\begin{tabular}{|c|c|c|c|c|c|c|c|}
\hline & Mean & Std deviation & Median & Std error & Interval & Min & Max \\
\hline Age & 33.1 & 3.9 & 33.5 & 0.74 & 16 & 24 & 40 \\
\hline BMI $\left(\mathrm{kg} / \mathrm{m}^{2}\right)$ & 23.1 & 1.8 & 23 & 0.41 & 6,6 & 20 & 26.6 \\
\hline Operation day & 145.4 & 22 & 147 & 4.16 & 89 & 95 & 184 \\
\hline Cervical dilation $(\mathrm{cm})$ & 2.5 & 0.8 & 2 & 0.15 & 3 & 2 & 5 \\
\hline Preoperative $\mathrm{CL}(\mathrm{mm})$ & 5.6 & 4.5 & 5 & 0.86 & 15 & 0 & 15 \\
\hline Postoperative $\mathrm{CL}(\mathrm{mm})$ & 30.8 & 5.3 & 30 & 0.99 & 21 & 22 & 43 \\
\hline Interval period (day) & 81.1 & 42.5 & 81 & 8.04 & 165 & 9 & 174 \\
\hline Labor day & 226.5 & 38.7 & 237.5 & 7.31 & 160 & 116 & 276 \\
\hline Birth weight (g) & 2268 & 984 & 2450 & 192.98 & 2730 & 850 & 3580 \\
\hline
\end{tabular}

BMI: body mass index; $\mathrm{CL}$ : cervical length.

\section{Results}

Twenty-eight cases whose full results obtained were included in our study. One case was excluded from the study as her results and family could not be reached. Mean age of the pregnant women was $33.5 \pm 4.4$ and their mean gravida was $1.75 \pm 1.2$. While 24 cases were primigravida $(85.7 \%)$ and 4 cases were multigravida $(14.3 \%)$, one case had the history of cerclage. Mean week of gestation when cerclage procedure was conducted was $20.9 \pm 3.2$, mean cervical dilation before the procedure was $2.5 \pm 0.8 \mathrm{~cm}$, and transvaginal cervical length was $5.4 \pm 4.5 \mathrm{~mm}$. Transvaginal cervical length after the procedure was $30.8 \pm 5.3 \mathrm{~mm}$. The clinical characteristics of the cases are shown in Table 1. No case had cervical injury or bleeding complication during or after the cerclage procedure.

In the follow-up of 28 cases, abortion was observed in $2(7.1 \%)$ cases. Twenty-six cases had live birth (92.9\%). Vaginal delivery was preferred in 4 cases $(15.4 \%)$ and cesarean section was performed in the remaining cases. Mean delivery week was $32.4 \pm 5.5$ and the mean period between cerclage and delivery was $81.1 \pm 42.5$ days (11.6 \pm 6.08 weeks). Preterm labor was seen in $76.9 \%$ (20/26) of the cases ( $<37$ weeks). Of these cases, $4(4 / 26 ; 14.3 \%)$ cases had excessively preterm labor (<28 weeks), $6(6 / 26 ; 23.1 \%)$ had premature preterm labor (28-32 weeks) and 10 (10/26; 38.5\%) had preterm labor between 32 and 37 weeks. Mean birth weight was $2268 \pm 984 \mathrm{~g}$. Twelve cases needed intensive care (7-50 days). Of these cases, when 3 died at the intensive care, neonatal mortality rate was found $11.5 \%$. Twenty-three $(82.1 \%)$ infants were discharged with full health and without any complication.

The characteristics of five cases with poor outcomes (two cases of pregnancy loss, and three cases of neonatal death) are shown in Table 2. The clinical data of the cases with poor outcomes and the cases with successful outcomes were compared. However, no significant difference was found between two groups in terms of maternal age, week of gestation when the procedure was performed, cervical dilation before the procedure, cervical length and cervical length after the procedure (p>0.05) (Table 3).

Table 2. Clinical characteristics of the cases with poor outcomes.

\begin{tabular}{|c|c|c|c|c|c|c|c|c|}
\hline Case & $\begin{array}{c}\text { Procedure } \\
\text { week }\end{array}$ & $\begin{array}{l}\text { CD } \\
(\mathrm{cm})\end{array}$ & $\begin{array}{c}\text { Preoperative } \\
\text { CL (mm) }\end{array}$ & $\begin{array}{l}\text { Postoperative } \\
\text { CL (mm) }\end{array}$ & $\begin{array}{l}\text { IP } \\
\text { (day) }\end{array}$ & DW & $\begin{array}{l}\text { BW } \\
\text { (g) }\end{array}$ & $\begin{array}{l}\text { HDNICU } \\
\text { (day) }\end{array}$ \\
\hline Abortion 1 & $14 w 2 d$ & 2 & 7 & 30 & 16 & $16 w 4 d$ & & \\
\hline Abortion 2 & $21 \mathrm{~h}$ & 5 & 0 & 30 & 9 & $22 w 2 d$ & & \\
\hline Death 1 & $18 w 1 d$ & 2 & 15 & 27 & 79 & $29 w 3 d$ & 980 & 14 \\
\hline Death 2 & $23 w 1 d$ & 2 & 0 & 24 & 32 & $27 w 5 d$ & 890 & 14 \\
\hline Death 3 & $21 w 4 d$ & 3 & 0 & 25 & 31 & $26 w$ & 850 & 3 \\
\hline
\end{tabular}

BW: birth weight; CD: cervical dilation; CL: cervical length; DW: delivery week; HDNICU: hospitalization duration at newborn intensive care unit; IP: interval period up to delivery. 
Table 3. Characteristics of the cases with successful and unsuccessful outcomes.

\begin{tabular}{lccc} 
& $\begin{array}{c}\text { Group 1 } \\
\mathbf{( N = 2 3 )}\end{array}$ & $\begin{array}{c}\text { Group 2 } \\
\mathbf{( N = 5 )}\end{array}$ & $\begin{array}{c}\mathbf{p} \text { - } \\
\text { value }\end{array}$ \\
\hline Age & $32.9 \pm 4.2$ & $34.2 \pm 1.9$ & 0.489 \\
BMI & $23.2 \pm 1.5$ & $22.9 \pm 3.4$ & 0.648 \\
Operation day & $147.1 \pm 21.7$ & $137.4 \pm 24.4$ & 0.589 \\
Cervical dilation $(\mathrm{cm})$ & $2.4 \pm 0.7$ & $2.8 \pm 1.3$ & 0.671 \\
Preoperative $\mathrm{CL}(\mathrm{mm})$ & $5.9 \pm 4$ & $4.4 \pm 6.7$ & 0.411 \\
Postoperative $\mathrm{CL}(\mathrm{mm})$ & $31.6 \pm 5.4$ & $27.2 \pm 2.8$ & 0.071 \\
Interval period (day) & $91.5 \pm 38.2$ & $33.4 \pm 27.3$ & 0.006 \\
Labor day & $238.7 \pm 27.2$ & $170.8 \pm 35.8$ & 0.002 \\
\hline
\end{tabular}

Group 1: successful cases; Group 2: unsuccessful cases; CL: cervical length.

\section{Discussion}

Cervical insufficiency is among the significant reasons of second trimester pregnancy losses and preterm labor, and it is characterized by the dilation of cervix without uterine contraction. The success, reliability, and necessity of emergency cerclage procedure in the presence of cervical dilation are controversial. However, in cases where the procedure is not or cannot be done, high rate of pregnancy loss has been reported. ${ }^{[9-13]}$ Ciavattini et al..$^{[9]}$ compared the clinical characteristics of 19 cases that are on bed rest and 18 cases that underwent emergency cerclage, who all received diagnosis at similar weeks. They found that the interval period $(16.8 \pm 7.9$ weeks $)$ up to delivery was significantly higher in the group which underwent emergency cerclage. They reported that the rate of term labor was $66.7 \%$ in this group while it was $10.5 \%$ in the group which was on bed rest. They found the rate of late pregnancy loss $5.5 \%$ and $52.6 \%$ in the cerclage group and bed rest group, respectively.

Stupin et al. ${ }^{[10]}$ retrospectively analyzed gestational outcomes of 182 cases with cervical insufficiency whose amniotic membrane prolapsed to vagina between 17 and 26 weeks of gestation, and they compared the gestational outcomes of 89 cases which underwent emergency cerclage with the gestational outcomes of 72 cases who underwent conservative procedure (bed rest, tocolysis and antibiotic treatment). They found that pregnancy was maintained significantly longer in cases which underwent cerclage (median period: 41 days vs. 3 days), and live birth rate was $72 \%$. They found live birth rate $25 \%$ in the group which underwent conservative procedure, and they concluded that cerclage procedure improved gestational outcomes significantly. Similarly,
Aoki et al.$^{[11]}$ found in their study that cerclage procedure significantly improved gestational outcomes. In this study, the authors reported that median week of gestation when the procedure was performed was 22.6 (range: 15.9-26.1 weeks), the procedure extended the pregnancy period for 44 (range: 4-165) days, and mean delivery week was 32.4 (range: 19.4-41.6) weeks. In the same study, the authors found pregnancy loss in $2(2 / 15$; $13.3 \%$ ) cases, preterm labor rate as $80 \%$ and excessively premature preterm labor rate as $20 \%$. Prasad et al..$^{[1]}$ analyzed 24 cases which underwent emergency cerclage in their study, and reported pregnancy loss $12.5 \%$, and preterm labor rate $42 \%$.

In our study, we also evaluated the cases which had cervical dilation and visible amnion membranes or prolapsed to vagina. The period extended by cerclage procedure was $81.1 \pm 42.5$ days and mean delivery week was $32.4 \pm 5.5$. We reported pregnancy loss in $2(7.1 \%)$ cases. Similar to the literature, we found the rate of preterm labor $76.9 \%$ and the rate of excessively premature preterm labor $14.3 \%$. With the loss of 3 cases out of 12 cases in need of intensive care, the neonatal mortality rate was $11.5 \%$ in our study. Twenty-three infants $(82.1 \%)$ were discharged to their home. Zhu et al ${ }^{[13]}$ reported the success rate of cerclage procedure $82.3 \%$ in their study. Mean number of extended days after the cerclage procedure was $52.2 \pm 26.6$ and mean delivery week was $30.3 \pm 4.7$. In their study, the authors reported labor rate $8.3 \%$ below 24 weeks of gestation and $12.7 \%$ at $24-28$ weeks of gestation, and they found term labor rate $10.8 \%$. Çok et al. ${ }^{[14]}$ published the results of 13 cases which underwent emergency cerclage (13-24 weeks) in their study and reported live birth in 11 ( $84.6 \%$ cases), mean waiting period 9 weeks and 4 days and mean delivery week 28 weeks and 3 days. They reported that the labor was carried out before 34 weeks of gestation in 8 cases $(72.7 \%)$.

It has been reported in the literature that some indicators can be used to predict the success of cerclage procedure. Amniotic membrane prolapse, presence of intraamniotic or systemic infection finding, presence of clinical symptom, and cervical dilation being $\geq 3 \mathrm{~cm}$ have been considered to be poor prognosis indicators. ${ }^{[1,15-17]}$ In our study, five cases had poor prognosis, there were two pregnancy loss cases, and three neonatal deaths due to prematurity-related problems. However, we did not find any significant difference between these cases and other successful cases in terms of cervical dilation, cervical length and cervical length after procedure. Insufficient number 
of cases or being the cases chosen from those in need of emergency cerclage (with cervical dilation and visible or prolapsed amniotic membrane) can be the reason. There are inconsistencies in the literature for the definitions of emergency cerclage and case selection. Therefore, this prevents proper evaluation of study results.

Wong et al ${ }^{[18]}$ reported the complications that may develop due to cerclage procedure as bleeding, cervicovaginal fistula, perioperative membrane rupture, postoperative premature rupture of membrane, pulmonary edema (tocolysis-related), deep vein thrombosis, chorioamnionitis and ablatio placentae. Zhu et al. ${ }^{[13]}$ followed up 158 cases in their study and reported cervical laceration in $2(1.25 \%)$ cases, pulmonary edema in 1 $(0.61 \%)$ case and deep vein thrombosis in $2(1.25 \%)$ cases. We found late pregnancy loss in two cases during the follow-up of our cases, but we did not observe any maternal complication.

\section{Conclusion}

In our study, we showed that the rates of pregnancy loss and preterm labor are decreased by cerclage procedure in the cases with cervical insufficiency requiring emergency cerclage.

Conflicts of Interest: No conflicts declared.

\section{References}

1. American College of Obstetricians and Gynecologists. Practice bulletin no. 142: cerclage for the management of cervical insufficiency. Obstet Gynecol 2014;123:372-9.

2. Debbs RH, Chen J. Contemporary use of cerclage in pregnancy. Clin Obstet Gynecol 2009;52:597-610.

3. Goldenberg RL, Culhane JF, Iams JD, Romero R. Epidemiology and causes of preterm birth. Lancet 2008;371 (9606):75-84.

4. Leduc L, Wasserstrum N. Successful treatment with the Smith-Hodge pessary of cervical incompetence due to defective connective tissue in Ehlers-Danlos syndrome. Am J Perinatol 1992;9:25-7.

5. Rackow BW, Arici A. Reproductive performance of women with müllerian anomalies. Curr Opin Obstet Gynecol 2007; 19:229-37.
6. Albrechtsen S, Rasmussen S, Thoresen S, Irgens LM, Iversen OE. Pregnancy outcome in women before and after cervical conisation: population based cohort study. BMJ 2008;337: a1343.

7. Shirodkar VN. A new method of operative treatment for habitual abortion in the second trimester of pregnancy. Antiseptic 1955;52:299.

8. McDonald IA. Suture of the cervix for inevitable miscarriage. J Obstet Gynaecol Br Emp 1957;64:346-50.

9. Ciavattini A, Delli Carpini G, Boscarato V, Febi T, Di Giuseppe J, Landi B. Effectiveness of emergency cerclage in cervical insufficiency. J Matern Fetal Neonatal Med 2016;29: 2088-92.

10. Stupin JH, David M, Siedentopf JP, Dudenhausen JW. Emergency cerclage versus bed rest for amniotic sac prolapse before 27 gestational weeks. A retrospective, comparative study of 161 women. Eur J Obstet Gynecol Reprod Biol 2008; 139:32-7.

11. Aoki S, Ohnuma E, Kurasawa K, Okuda M, Takahashi T, Hirahara F. Emergency cerclage versus expectant management for prolapsed fetal membranes: a retrospective, comparative study. J Obstet Gynaecol Res 2014;40:381-6.

12. Prasad NN, Thampan SA, Nagarathnamma R. Emergency cervical cerclage and pregnancy outcomes. Int J Reprod Contracept Obstet Gynecol 2017;6:1993-8.

13. Zhu LQ, Chen H, Chen LB, Liu YL, Tian JP, Wang YH, et al. Effects of emergency cervical cerclage on pregnancy outcome: a retrospective study of 158 cases. Med Sci Monit 2015; 21:1395-401.

14. Çok T, Özdemir H, Kalaycı H, Yetkinel S, Aytaç PÇ, Tarım E. Single-center 4-year outcomes of patients underwent cervical cerclage to prevent preterm labor. Perinatal Journal 2016; 24:1-5.

15. Gupta M, Emary K, Impey L. Emergency cervical cerclage: predictors of success. J Matern Fetal Neonatal Med 2010;23: 670-4.

16. Namouz S, Porat S, Okun N, Windrim R, Farine D. Emergency cerclage: literature review. Obstet Gynecol Surv 2013;68:379-88.

17. Steenhaut $P$, Hubinont $C$, Bernard $P$, Debiève F. Retrospective comparison of perinatal outcomes following emergency cervical cerclage with or without prolapsed membranes. Int J Gynaecol Obstet 2017;137:260-4.

18. Wong GP, Farquharson DF, Dansereau J. Emergency cervical cerclage: a retrospective review of 51 cases. Am J Perinatol 1993;10:341-7.

Bu makalenin kullanım izni Creative Commons Attribution-NoCommercial-NoDerivs 3.0 Unported (CC BY-NC-ND3.0) lisansı aracılığılya bedelsiz sunulmaktadır. / This work is licensed under the Creative Commons Attribution-NonCommercial-NoDerivs 3.0 Unported (CC BY-NC-ND3.0) License. To view a copy of this license, visit http://creativecommons.org/licenses/by-nc-nd/3.0/ or send a letter to Creative Commons, PO Box 1866, Mountain View, CA 94042, USA. 